\title{
The Social Position and Intellectual Identity of the Renaissance Mathematician-Physicist Giovanni Battista Benedetti: A Case Study in the Socio-Political History of Mechanics
}

\author{
Pietro Daniel Omodeo \\ Ca' Foscari University of Venice \\ ERC Endeavor EarlyModernCosmology (GA 725883)
}

\begin{abstract}
:
The scientific work of Giovanni Battista Benedetti, one of the founding fathers of modern mechanics, is an apt test case of socio-political history of science. It can help us to address the tension between social position and intellectual identity of Renaissance scholars who formed the archetype for modern scientists. I deal in this chapter with the manner in which socio-political coordinates informed Benedetti's science as far as (1.) its demarcation, (2.) content, (3.) form and (4.) justification are concerned. With social coordinates I refer to the institutional setting involving Benedetti's role as a courtier and thus to his function as a court mathematician which, in turn, was linked to the wider socio-economic interests of a Renaissance territorial state. With cultural coordinates I refer to Benedetti's intellectual identity as a mathematician as well as his political identification with the wider interests of the Savoy ruling class. The polarity of function and identity constitutes the hermeneutic instrument for my interpretation of Benedetti's science. Such a dialectic of position and identity should serve as a guide for a non-reductionist socio-cultural case study in the history of science.
\end{abstract}

\section{Keywords:}

- Socio-political history of mechanics

- Social position of the Renaissance scientist

- Political identity of the Renaissance scientist

- Science and the court

- Giovanni Battista Benedetti

- Renaissance Turin

The historian of medieval science and philosophy Anneliese Maier viewed Giovanni Battista Benedetti with mixed feelings. To her Benedetti appeared as a sort of intellectual companion of Galileo Galilei, at the same time his "forerunner" in mathematical physics and a disrespectful epigone of earlier medieval Vorläufer or predecessors. Parisian scholastics such as Nicole Oresme and Johannes Buridane provided Bendetti and Galileo with concepts to inquire into physics - Maier particularly had the concept of impetus in mind-which they did 
not acknowledge in their fierce attack against Aristotelian philosophy. ${ }^{1}$ Maier shared Alexandre Koyré's view that modern mechanics was constructed around a few central concepts that essentially derived from Newton's Principia mathematica. Although I do not embrace the reductionist and idealistic interpretation of these historians, I mention their perplexity concerning the reception/rejection of medieval physics by Renaissance scientists to bring into focus the question of the cultural conditions for the incipient querelle des anciens et des moderns. ${ }^{2}$ Nicolaus Copernicus, a sort of "unaware revolutionary," "3 saw himself (or at least presented himself) as a Renaissance restorer of planetary theories, defended in antiquity by legendary Pythagoreans, whereas his scholastic counterpart, the Paduan Averroist Girolamo Fracastoro, presented a homocentric reform of mathematical astronomy (based on the modeling of all celestial motions through concentric spheres, in line with an Islamic/Aristotelian tradition), as a radical innovation, comparable with Amerigo Vespucci's discovery of a New World. ${ }^{4}$ In the case of Benedetti, which I will focus on here, the rejection of the philosophia naturalis taught in the universities was achieved with intellectual means descending from that very philosophical tradition. Rather than viewing this fact as a paradox, it should be regarded as a sign of a profound tension in Renaissance science between the intention to outdo traditional authorities in order to move beyond their legacy on the one hand, and the necessity to rely on the shared knowledge of the time, marked by Aristotelian thought, on the other. In the following essay I will delve into Benedetti's conceptions and reconstruct their socio-cultural coordinates.

The polarity between continuity and discontinuity arguably reflects a more general tension between the material and intellectual conditions of early modern science as well as between the intentions and identities of a new genre of intellectuals, who formed the archetype for modern scientists. Benedetti's case will help us reflect on the social position and intellectual identity of such new types of scholars as well as on the way socio-cultural coordinates penetrated science, as far as (1.) its demarcation, (2.) content, (3.) form and (4.) justification are concerned. With social coordinates I refer to the institutional setting involving Benedetti's role as a courtier and thus to his function as a court mathematician which, in turn, was linked to the wider socio-economic interests of a Renaissance territorial state. With cultural coordinates I refer to Benedetti's intellectual and political identity. The former identity refers to Benedetti's philosophical interpretation of his role as a mathematician; the latter to his identification with the wider interests of the Savoy ruling class. I do not see these cultural coordinates as determined by the social environment but rather as the ethical-political pendant of the socio-economic context, following Gramsci's dictum: "Material forces are the content and ideologies the form, according to a merely didactic distinction between form and content, since the material forces cannot be historically conceived without any forms and the ideologies would be individual whims separated from

\footnotetext{
${ }^{1}$ Maier (1951, 304-305) established a connection between Benedetti's treatment of motion and that of Galileo.

2 See Lehner and Wendt (2017).

${ }^{3}$ Copernicus' revolutionary role malgré soi already puzzled Thomas S. Kuhn, who called him at once "radical" and "conservative" and regarded De revolutionibus orbium coelestium, the book propounding the first modern heliocentric theory in mathematical astronomy, "revolution-making" rather than "revolutionary." Cf. Kuhn $(1959,135,148)$.

${ }^{4}$ See Goddu (2010); Granada and Tessicini (2005); and Omodeo (2017b).
} 
the material forces." 5 The polarity of function and identity constitutes the hermeneutic instrument for my interpretation of Benedetti's science. Such a dialectic of position and identity should serve as a guide for a non-reductionist socio-cultural case study in the history of science.

\section{The Demarcation of Early Modern Mechanics: An ex post Perspective}

The athletic metaphor of the "forerunner" does not have to be taken literally as a teleological claim. In reference to Benedetti it is simply meant to emphasize his outstanding originality, his capacity to advance along new intellectual paths enabling subsequent generations to explore physics further. Historians of mechanics have often extolled Benedetti's contributions to the science "of balance and motion." As a matter of fact, a direct link could be established between his Archimedean treatment of heavy bodies falling through a medium and Galileo's early writings De motu. ${ }^{7}$ Moreover, the young Galileo and his patron Del Monte scrutinized Benedetti's De mechanicis, a work that provided decisive insights for the conceptualization of what Galileo would refer to as "momento" or torque. ${ }^{8}$ Because of these connections historians of science allotted Benedetti a central position in the Renaissance debates on mechanics. To single out and better locate his contribution, I begin with a more general treatment of the theoretical scope of early modern mechanics, in the form of an ex post perspective derived from a significant late seventeenth-century account. As a second step, I will integrate this tentative outline with a socio-cultural critical reworking.

Concerning the systematic peculiarities and developmental lines of mechanics in the early-modern period, it can be remarked that prima facie this scientific field does not present "demarcation" difficulties. The first theoretical and historical outline of the discipline, which was idealized but nevertheless insightful, can be found in Joseph-Louis Lagrange's Mécanique analytique (first ed. Paris, 1788). This work, which completed the process of subsuming mechanics under the field of mathematical analysis, can be seen as the systematical culmination of early modern mechanics. ${ }^{9}$

According to Lagrange's disciplinary partitions, familiar to today's reader, mechanics comprises two main areas, statics and dynamics. These are in turn subdivided depending on whether they examine solid bodies or liquids. He defined statics as "the science concerned with the balance of forces," and summarized its three fundamental laws: balance of the lever (équilibre dans le levier), composition of motions (composition des mouvements), and virtual work (vitesses virtuel). Lagrange integrated this theoretical schematization with a brief summary of the history of the discipline by specifying the names of the "discoverers" of the

\footnotetext{
${ }^{5}$ See Gramsci (1975, Notebook VII, 869): "le forze materiali sono il contenuto e le ideologie la forma, distinzione di forma e contenuto meramente didascalica, perché le forze materiali non sarebbero concepibili storicamente senza forma e le ideologie sarebbero ghiribizzi individuali senza le forze materiali."

${ }^{6}$ Ernst Mach's Die Mechanik in ihrer Entwicklung historisch-kritisch Dargestellt began with this field demarcation: "Jener Teil der Physik, welcher der älteste und einfachste ist und daher auch als Grundlage für das Verständnis vieler anderer Teile de Physik betrachtet wird, beschäftigt sich mir der Untersuchung der Bewegung und des Gleichgewichts der Massen. Er führt den Namen Mechanik" (1912, 25).

${ }^{7}$ Cf. Drabkin $(1960,3-12,10-11)$.

${ }^{8}$ Cf. Renn and Damerow (2011).

${ }^{9}$ See Lagrange (1788, vi): “Ceux qui aiment l'Analyse, verront avec plaisir la Méchanique en devenir une nouvelle branche, et me fauront gré d'en avoir étendu ainsi le domaine.”
} 
various principles, laws, and ingenious solutions to mechanical problems. In addition to the definition of general principles and laws and the solution of special problems, he considered simplification and unification to be significant to the progress of a mathematical discipline.

He presented the law of the lever as the most ancient law of statics. It was determined by Archimedes and reworked by Stevin and Galileo among the moderns. The reduction of the other simple machines, in particular the inclined plane, to the lever was envisaged by Pappus in ancient times but solved and brought to perfection only by modern scholars such as Stevin and others. A second law of statics, the composition of motions, was first established by Galileo and improved by several scholars: Descartes, Roberval, Mersenne, Wallis and Varignon. A third law is traced back to Galileo's concept of momento. ${ }^{10}$ Galileo is also presented as the initiator of the "entirely modern" part of mechanics, namely dynamics as the "science of accelerating and decelerating forces and of the varied motions that they can produce." 11 It originated from the attempts to find a mathematical solution to physical problems such as the fall of bodies and the determination of projectiles' trajectories and, later on, the pendulum and centrifugal forces as studied by Huygens. Newton's discovery of universal gravitation enabled the definitive metamorphosis of mechanics into a science nouvelle. Eventually, the invention of calculus permitted mathematicians to express the laws of the motion of bodies in the form of equations. As far as the variation of speed of motions is concerned, the crucial improvements concerned the introduction of the idea of inertia and the composition of motions. Furthermore, the field was expanded through the study of bodily interactions during the seventeenth and eighteenth centuries by Descartes (conservation of motion) and Huygens (conservation of energy). The discipline reached perfection thanks to the work of the likes of Jean and Daniel Bernoulli, d'Alembert, and Euler, to mention only a few of the mathematicians whom Lagrange viewed with admiration. Additionally, the principle of least action (principe de la moindre action) was developed in the wake of Maupertuis's quasi-metaphysical application of the principle to both light refraction and bodily shocks. ${ }^{12}$ Here is not the place to expand on these developments of seventeenth and eighteenth-century mechanics but it is important to mention them as part of the wider picture. ${ }^{13}$ Furthermore, the intellectual dimension of Lagrange's treatment of mechanics could be helpful as a reference point to systematically map the mental models of "classical" mechanics.

The schema that emerges from Lagrange's historical outlook is not intricate. It can be summarized as a three-step advance of the discipline. The Renaissance systematization of ancient and medieval mechanics came first, along with the creation of dynamics as a specifically modern field of physical-mathematical inquiry. The second step consisted in the generalization of the science of machines into a general mathematical physics up to Newton. Third, mathematical formalism permitted the analytical treatment of mechanics and led to its complete transformation into a deductive analytical mathematical discipline. I would

\footnotetext{
${ }^{10}$ Today, the reference work on this is Galluzzi (1979).

${ }^{11}$ See Lagrange $(1788,158)$ : "La dynamique est la Science des forces accéleratrices ou retardatrices, et des mouvemens variés qu'elles peuvent produire."

${ }^{12}$ Lagrange $(1788,188)$ : “Ce principe envisagé analitiquement, consiste en ce que dans le mouvement des corps qui agissent les uns sur les autres, la somme des produits des masses par les vitesses et pare les espaces parcourus, est un minimum."

${ }^{13}$ For a thorough study of the developments of mechanics up to Lagrange, see Pulte (1989).
} 
concisely label the three main phases of early modern mechanics as follows: first, mechanics as the science of machines, second, mechanics as the physical-mathematical science of balance and motion in general and, third, mechanics as an analytical science.

However, upon inspection Lagrange's clarifications are too general for a historical understanding of the boundaries of the discipline and its differentiation into sub-fields. His demarcation is clearly a posteriori relative to the tumultuous age in which Benedetti and Galileo lived and does not account for the historical development of the discipline. The definition of mechanics as the science of balance and motion and the corresponding distinction of its two main branches was itself the result of a historical process of generalization and differentiation. Moreover, as soon as one raises questions about the link of mechanics with allied sciences, methodology, the context of justification or the cultural meaning and impact, the demarcation of early modern mechanics becomes less sharp and the investigation has to take into account the emergence of the discipline owing to both intellectual and material circumstances. In other words, Lagrange took a snapshot of the discipline at a certain stage of its evolution. Therefore, his schemas are useful but intrinsically limited; their rigid application and uncritical reception would imply re-reading the past anachronistically. In fact, they cannot account for the concrete development of mechanics unless one assumes, first, that scientific disciplines are meta-historical hypostases and, second, that their progress is teleologically guided by inner principles. I regard none of these presuppositions as tenable. Rather, mechanics emerged from a concrete historical ground and was progressively differentiated, articulated, and organized. It is the task of the historian of science to reconstruct the paths mechanics took before it crystallized into certain forms at certain stages.

Scholars such as Ernst Mach only partly overcame the limitations inherent to a purely speculative treatment of mechanics. Mach did not question Lagrange's indication of the main problems and themes of the science of mechanics, but integrated it with historicalepistemological considerations in Die Mechanik in ihrer Entwicklung historisch-kritisch Dargestellt (Science of Mechanics: A Critical and Historical Account of Its Development) (Leipzig, 1883). In particular, Mach insisted that the discipline was founded upon experience, although the social aspect of the concept of experience escaped his analysis. The importance of this social dimension was stressed by Leonardo Olschki in his three volumes on the Geschichte der neusprachlichen wissenschaftlichen Literatur (History of Vernacular Scientific Literature) (1919, 1922, 1927). As has already been discussed, Marxist historiography in the 1930 s and 1940 s pointed out the social roots of science, especially thanks to the Soviet historian of science, Boris Hessen, and the German Marxist émigré in the USA, Edgar Zilsel. ${ }^{14}$ Hessen listed the economic realms and social spheres accounting for the content of mechanics in the age of Newton. ${ }^{15}$ Alongside the Polish affiliate to the Frankfurter Schule, Henryk Grossman, he stated that modern mechanics resulted from a reflection on available machine technology in an age in which the emergence of the capitalist society valued the economic relevance of technology. Zilsel expanded the social discussion on the rise of modern mechanics by indicating its producers, that is, the early scientists who brought

\footnotetext{
${ }^{14}$ See Long (2011, ch. 1), and Omodeo (2017a, 119-150).

${ }^{15}$ See Hessen $(2009,41-102)$.
} 
together artisanal experience, the scholastic spirit of systematization, and humanistic literacy. ${ }^{16}$ These scholars merely hinted at the relevance of the interplay of cultural and political drives with the socio-economic foundation (Basis), regarding this issue as a problem of ideology (Hessen) or as one related to the reconstruction of the cultural background of socalled "knowledge bearers" (Zilsel). While Hessen considered the incidence of ideology to be limited to the limitations of early modern scientific conceptions and Zilsel restricted himself to the analysis of the social function of early scientists, the constitutive dimension of politics and culture and the identity of scientists as intellectuals remained obscure to them, owing to an overall economicist understanding of history and society. As I argued before, the integration of the structural dimension with the political-cultural can be achieved through a methodological reappraisal of Gramscian views concerning the vital connection of the social and the political well captured by the concept of hegemony. ${ }^{17}$ Beginning with these premises, I will first present Benedetti's work on mechanics in general and then focus on its two constitutive elements, social position and intellectual identity.

\section{Benedetti's Writings on Mechanics}

Benedetti developed his mechanics in a stage in which the physical-mathematical treatment of balance and motion was not sharply separated from the investigation of concrete machines and the solution of technological problems, although it showed evident bias toward generalization at the level of mathematical abstraction and the foundations of physics or "natural philosophy." We can aptly locate Benedetti's mechanics in that pre-Newtonian compartment which has been defined as the phase of preclassical mechanics by taking Newton's Philosophiae naturalis principia mathematica to be the theoretical watershed. In fact, one can assume for the sake of simplicity - that is, by abstracting from the internal tensions in Newton's work and its complex reception-that the discipline reached its classicism after this publication in $1687 .{ }^{18}$ Benedetti's approach was marked by its connection with practice, although, as I will argue, his approach and level of formalization of mechanics reveals an accomplished division of labor between the scientist who knows, assesses and projects, and the craftsman, or practitioner, who is experienced and realizes wonderful works but lacks a general understanding of their principles and laws. In his role as the court mathematician Benedetti embodied the former category. He was aware of the theoretical dimension of mechanics and the relevant sources; in particular, he benefitted from the reappropriation of Archimedes' mathematical work, including his hydrostatics, the reworking of (pseudo-)Aristotle's Mechanical Problems, the merging of these reception lines with Jordanus Nemorarius' scholastic scientia de ponderibus, and the rise of innovative perspectives such as Tartaglia's ballistics, a nova scientia in its own right (1537), and Del Monte's determination of the center of gravity as a unifying explanatory principle of simple machines (in Mechanicorum liber, 1577). ${ }^{19}$

\footnotetext{
${ }^{16}$ See Zilsel (2000).

${ }^{17}$ See Chapter 3 "Socio-Political Coordinates of Early Modern Mechanics: A Preliminary Discussion" in this volume.

${ }^{18}$ Cf. Damerow et al. (2004).

${ }^{19}$ For an overview, see Drake and Drabkin (1969, "Introduction," 3-60). Dijksterhuis (1956) remains a valid introduction to Archimedes. On the reception of his hydrostatics, see Chalmers (2017). On Aristotelian
} 
Benedetti's most significant contributions to mechanics are scattered in several works of his: Resolutio omnium Euclidis problematum (Resolution of All of Euclid's Problems) (Venice, 1553), Demonstratio proportionum motuum localium contra Aristotilem et omnes philosophos (Demonstration of the Proportions of Local Motions against Aristotle and All Philosophers) (Venice, 1554 and, second revised edition, 1555), and his major work, Diversarum speculationum mathematicarum et physicarum liber (Book of Various Mathematical and Physical Speculations) (Turin, 1585), in particular in the third and fourth books entitled De mechanicis (On Mechanics), Disputationes de quibusdam placitis Arist[otelis] (Disputations on Some of Aristotle's Opinions), and in some of the epistles comprised in the last part of the Diversarum speculationum ... liber. ${ }^{20}$ The issues he dealt with included debated topics of mechanics in his time such as the determination of the equilibrium of balances, body's free fall, and cannonballs' trajectories. As for his theoretical achievements, Benedetti has been extolled for his treatment of fall acceleration as an increasing impetus and the conclusion that bodies of the same material fall with the same speed; he defended this view in explicit opposition to the widespread Aristotelian theory that speed is proportional to the weights of the falling bodies. ${ }^{21}$ By considering the properties of turning wheels, he explained centrifugal tendencies in terms of an inclinatio recte eundi (inclination to move straightforward) in a fashion that is very close to Galileo and Descartes' later approaches. Further, Benedetti's theoretical connection of the mechanics of turning objects with the physical discussion of the Copernican motion of the Earth constituted a premise for further articulations of the problem in the Dialogo sopra $i$ due massimi sistemi del mondo (1632) and Le Monde ou Traité de la lumière (written around 1632). ${ }^{22}$ Benedetti's inquiry of falling bodies was the basis for Galileo's early exploration of this area, while his conceptualization of equilibrium is very close to that of torque. Moreover, Benedetti consistently applied a mathematical approach to physics. He relied on the mathematical instruments he had at his disposal, that is, geometry (though not yet mathematical analysis). Just like Galileo and his school, Benedetti used the theory of proportions, derived from Euclid, as the key intellectual tool for the mathematical treatment of physical phenomena. ${ }^{23}$

The aforementioned contributions are substantial, and have justifiably been singled out by historians of science, but are not sufficient to comprehend the scope and the meaning of Benedetti's endeavor. In fact, his work shows great heterogeneity and the horizon of his interests reaches far beyond the boundaries of mechanics as they were established in the constitutive period for this field. Although he was convinced of the excellence of his own

\footnotetext{
mechanics, see van Leeuwen (2016). See also Nenci (2011). On other important aspects of the renewal of mechanics during the Renaissance, see Renn and Damerow (2010, 2011); Valleriani (2013); Becchi et al. (2013). ${ }^{20}$ The standard reference work on Benedetti is Bordiga (1985). For a new general introduction to Benedetti's major work, see Omodeo and Renn, Science in Court Society (in press).

${ }^{21}$ See Maccagni (1967).

${ }^{22}$ Cf. Omodeo and Renn, Giovanni Battista Benedetti's Science in Court Society (in press), ch. 4. Benedetti's importance for the development of the concept of inertia has been stressed by Koyré [1939] 1966, 47-60. As Koyré remarks $(1966,122)$ : "Jean-Baptiste Benedetti est très certainement le physicien italien le plus interessant $\mathrm{du} \mathrm{XVI}{ }^{\mathrm{e}}$ siècle; il est aussi celui dont le rôle historique fut le plus important: en effet, son influence sur le jeune Galilée qui, dans son traité de Motu, le suit pas à pas, est indéniable et profonde."

${ }^{23}$ Cf. Giusti (1993).
} 
inquiry in mechanics as "science of machines," ${ }^{24}$ he did not isolate it from a wider mathematical and natural-philosophical investigation-nor did he isolate mathematics from practice and technology. Benedetti's first publications on mechanical issues appeared together with mathematical studies on Euclidean geometry. At the same time, he cast horoscopes - an activity requiring astronomical and computational competence - and was acknowledged for this by some of the leading astrologers of the time. The most reputed among them, Luca Gaurico, included in his famous Tractatus astrologicus (Venice, 1552) a nativity of Benedetti calculated by Benedetti himself. ${ }^{25}$ In his mature years as a court mathematician in Turin, he wrote on apparently disparate subjects. They ranged from the theory and construction of sundials (e.g., De gnomonum umbrarumque solarium usu liber, 1574) to polemical writings on the reliability of ephemerides computation (e.g., Lettera... intorno ad alcune nuove riprensioni, et emendationi contra alli calculatori delle effemeridi, 1581), disputes on the quantitative proportion of water and earth in the terrestrial globe (Consideratione .... d'intorno al discorso della grandezza terra et dell'acqua, 1579), astrological reports and technical advice on measurement instruments. ${ }^{26}$ His major work, Diversarum speculationum mathematicarum et physicarum liber, shows the unsystematic attitude of the author. Indeed, it is a miscellany of writings on the most varied topics and a document of his wide-ranging interests. The first book is a collection of mathematical exercises offering geometrical solutions to arithmetic problems, the second deals with problems of perspective relevant to architecture, the third with mechanics, the fourth with motion, natural philosophy and postCopernican cosmology, and the fifth with Euclid's theory of proportions. The sixth book is a collection of epistles containing Benedetti's advice on countless topics: a project of calendar reform, navigation, machines, ballistics, engineering, geography, literature, mathematical philosophy and much more.

What is the common denominator of the great variety of subjects dealt with by Benedetti? What is the center around which they all gravitate? Is there one unifying principle behind the apparent disorder and heterogeneity? It should be emphasized that Benedetti first established his fame as a mathematician. His early treatment of motion by mathematical means was explicitly directed "against Aristotle and all philosophers" (contra Aristotilem et omnes philosophos). In his time "mathematics" had a wide scope. It comprised arithmetic and geometry, astronomy and astrology, and music, but also reached far beyond the boundaries of the quadrivium by encompassing optics, practical mechanics, architecture, and engineering. The expansion of mathematics into the fields of physics, natural philosophy, meteorology, and even metaphysics and epistemology was a crossing, a franchissement, of the disciplinary boundaries. Benedetti's time bears witness to several attempts to expand the boundaries of mathematics. Cardano, for one, claimed that geometry had the function of a universal logic

\footnotetext{
${ }^{24}$ In his major work, Diversarum speculationum mathematicarum et physicarum liber, 141, Benedetti introduced his section De mechanicis as follows (trans. Drake and Drabkin 1969, 166): "Now it is my desire to publish a few items that will, I believe, prove not unwelcome to those who concern themselves with mechanics, items which have never before been dealt with or have not been sufficiently well explained. I may thus either show my desire to be helpful or at least give some evidence of possessing a bit of talent and industry. And perhaps in this way alone may I leave behind me proof that I ever lived at all.”

${ }^{25}$ See Gaurico (1552, f. $76 r$ ).

${ }^{26}$ See, among other publications on this lesser-known scientific production of Benedetti, Roero $(1997,37-66)$ and Mammola (2014).
} 
fundamental to rational thought, and that the practical disciplines including statics, mechanics, and architecture were its subordinate fields of inquiry. ${ }^{27}$

Benedetti's intellectual identity, however, proves much more complex than the corporate identity as a mathematician. ${ }^{28}$ His pronounced titles vary. In a short biographical note accompanying the birth horoscope published by Gaurico he was indicated as "Phylosophus, Musicus, atque Mathematicus"; on 19 October 1589 he signed an astrological report cast for Carlo Emanuele as "Matematico e Astrologiaro"; 29 a lost manuscript collection of epistles of his was entitled Lettere di Giovanni Battista Benedetti, Veneziano, matematico del Duca Emanuele Filiberto e Carlo Emanuele I, but this reference is a later cataloging entry as indicated by the numbering of Carlo Emanule as "first"; contemporary admirers of his such as the Milan painter and poet, Giovanni Paolo Lomazzo, and the Danish astronomer, Tycho Brahe, called him "matematico" and "philosophus et mathematicus inprimis excellentem," respectively. ${ }^{30}$ Probably, Brahe's designation of Benedetti as both philosopher and mathematician best captures the poles of his intellectual activity. Intriguingly enough, Benedetti generally dropped the title of "mathematician" keeping only that of "philosopher" in his publications. On the title page of his magnum opus, the Diversae speculationes (first edition, 1585), he appears as "patritius Venetus philosophus," exactly the same epithet that appears in De gnomonum umbrarumque solarium usu liber (1574). In the publications in the vernacular, he correspondingly appears as "filosofo del sereniss. duca di Savoia," for example, in the Consideratione .... d'intorno al discorso della grandezza terra et dell'acqua (1579). In the last publication, his self-presentation as court philosopher is interestingly opposed to the designation of his intellectual opponent, Antonio Berga, as "filosofo nella Università di Torino," that is "university philosopher"-which is equivalent to scholastic philosopher. These references are telling either for Benedetti's self-perception or, to use an invogue expression, his self-fashioning. ${ }^{31}$ In both cases, the image of court philosopher was his intended identity, whether reflected or purposely constructed (or a mixture of both). As was the case with Galileo, the Florentine courtier, the philosopher's social status and reputation was higher than that of the mathematician. This is why, among the conditions for Galileo's appointment as a courtier to the Medici, he regarded the designation "philosopher" as relevant. ${ }^{32}$ As for the epistemological debates mirroring the disciplinary and social divides and hierarchies of the time, heated controversies began over the "certainty of mathematics." The determination of the degree of certainty of mathematics also concerned the legitimacy of using mathematics in physics. ${ }^{33}$ In the case of Benedetti, the tension between his function as court mathematician and his identity as philosopher-and patrizio-underlies his science. While philosophical legitimacy was essential for the acknowledgment of the intellectual dignity of his endeavor, the practical dimension of mathematics remained fundamental for the

\footnotetext{
${ }^{27}$ See Cardano (1966) and Omodeo (2017b).

${ }^{28}$ By "corporate" I refer to the esprit de corps of a group that considers itself a bounded entity whose interests are marked as separate from other groups. This particular meaning of corporation originated with the guild culture of the Middle Ages and it precedes the modern sense of a professional group or legal body.

${ }^{29}$ See Roero (1997, 57-58).

${ }^{30}$ Lomazzo (2006, 177): “Del Sig. Gio. Battista Benedetti Matematico”; Brahe (1916, 251-253).

${ }^{31}$ The expression stems from Greenblatt (1980).

32 This theme is discussed in detail in Biagioli $(1989,1993)$.

${ }^{33}$ For an insightful treatment of the Renaissance debates on the certainty of mathematics, see Axworthy (2016).
} 
social justification of his function as a court expert. These poles, socio-functional and identity-cultural, taken together-and only if considered together!-account for the content and demarcation of Benedetti's science, its form and its legitimacy.

\section{The Social Position of an Early Modern Court Mathematician}

For most of his life, Benedetti's social position was that of a courtier, or to be more precise, "a court mathematician." This was the setting in which Benedetti fully developed his scientific activity. After a few years in Parma with duke Ottavio Farnese, he entered the Savoy court in Turin to serve the duke Emanuele Filiberto and his successor, Carlo Emanuele, from 1567 up to his death in 1590 . His commitment to the ruling family was sanctioned by the bestowal upon him of the privileges of imperial nobility in 1570. This also marked his social ascent from Venetian patriziato - a title he would never renounce- to higher aristocracy.

In those years, the territorial state of Savoy was going through a difficult transition toward a centralized "court society". After the restoration of the Duchy in 1559, after more than twenty years of French occupation, Turin became the new capital replacing Chambéry. ${ }^{34}$ The dukes strove to transform it into a "modern" town, partly following the model of Florence, insofar as culture and prestige were concerned, but also the Spanish and French models, insofar as the suzerainty of the ruling family was concerned. Military force, administrative rigor, and international diplomacy were necessary for the survival of a buffer state between aggressive powers, France and Spain (as it bordered with Spanish Lombardy). Within a framework of modernization (which I would call a "passive revolution" as it implied the top-down importation of foreign models) taxation was reformed and the vernacular was imposed as the language of the administration. Following the Swiss example, obligatory conscription of all male subjects was imposed. Other models played a role, too, for instance Dutch military technology, which Emanuele Filiberto had come across during his campaigns as the chief commander of Charles V's imperial army in Flanders in 1556. New fortresses were built on the Alps and a citadel was erected between 1564 and 1566 in accordance with the most up-to-date precepts of military engineering. ${ }^{35}$ Patronage attracted artists and writers as much as architects. ${ }^{36}$ The most famous among them, Andrea Palladio, dedicated his Quattro libri dell'architettura (Four Books on Architecture) (Venice, 1570) to the duke of Savoy and probably drafted the plan of the park of Viboccone for him, in which Benedetti is said to have constructed a fountain. ${ }^{37}$ For reasons of prestige, as well as cultural hegemony in the field of education, the duke reopened the university, which had been closed during the foreign occupation, and attracted some of the most reputed professors of philosophy, medicine, and humanities of the time. ${ }^{38}$

Thus, Turin took the shape of a Renaissance capital in which the court was a hegemonic center from which powerful élites mediated between the ruler and the socio-

\footnotetext{
${ }^{34}$ For a comprehensive historical reconstruction of Turin in this time, see Ricuperati (1998).

35 See Pollak (1991).

${ }^{36}$ See Doglio (1998).

${ }^{37}$ Cf. Tessari (1993). On Benedetti’s fountain, see Maccagni (1967, 353-354).

${ }^{38}$ See Catarinella and Salsotto (1998).
} 
political environment. Following the sociologist Norbert Elias, one can regard court society as a transitional social formation (gesellschaftliche Figuration) in European history between feudalism and industrial capitalism. A distinguishing feature of court society was the centralization of power and administration around the court. Its culmination was the absolutism of the Ancien Régime, prepared and imitated at a smaller scale by local efforts directed toward administrative and political centralization. ${ }^{39}$ Although such social formations apparently depended on an individual sovereign taking all decisions (as much of the literature of the time on the principe and his privileges boasted), ${ }^{40}$ it was rather a hierarchical system in which the group of experts surrounding the ruler constituted an oligarchy making the complex organization of modern states possible. Hence, the court was a political, economic and cultural hub, in which a class of experts mediated between the center of decision-making and the administrated periphery. Benedetti was one of these experts; his specific competence was mathematics. He shared the enthusiasm of his patrons (especially Emanuele Filiberto's) for mathematics and its perceived potency as an instrument for successful navigation in war and peace. ${ }^{41} \mathrm{He}$ was expected to supervise engineering and architecture projects, to produce instruments or machines for practical purposes, warfare, and recreation (such as fountains, sundials or nautical instruments). He was also expected to properly interact with the upper classes, respecting aristocratic etiquette and adhering to shared court values, norms and behaviors, first of all those linked to honor and prestige. ${ }^{42}$ He had to act as the Savoy "expert" on pedagogical and technical issues linked to his profile as a mathematician and mathematical philosopher.

The primacy of courtly interests over those of science as an autonomous disciplinary endeavor can best be illustrated by considering Benedetti's correspondence. The last book of the Diversae speculationes is a large collection of letters, "Physica et mathematica responsa" (Answers on Physics and Mathematics). He introduced them with the following remark:

To the reader.

Nothing is more suited to virtue than being active and present through constant motion. Just like a shining star shimmering for the eyes of the spectators. It occurred to me that this or that person invited me with words or stimulated me with letters to dispute on those issues in which I am versed. In fact, I was devoted to mathematics and to highly philosophical speculations while I sojourned in the most splendid princely courts and illustrious cities, where many intelligent people displayed admirable curiosity, desire for knowledge and for discourse. I collected parts of those disputes and answers, because I judged them to be worth transmitting. I planned to reread and revise them, if I had some

\footnotetext{
${ }^{39}$ See Norbert (2002, 73): "Durch das Bemühen um dis Struktur der höfischen Gesellschaft und damit um das Verständnis diner der letzten großen niche-bürgerlichen Figurationen des Abendlandes eröffnet man sich also mittelbar zugleich einen Zugang zum erweiterten Verständnis der eigenen berufsbürgerlich-städtischenindustriellen Gesellschaft."

${ }^{40}$ Doglio (2005).

${ }^{41}$ Emanuele Filiberto's passion for mathematics was well documented. Among others, the Venetian ambassador to Turin Giovanni Correr reported on it in 1566: "That duke is no man of letters but he loves the virtuosi. Hence, he has many of them by him; he likes to listen to their reasoning and he asks them questions. However, there is no subject that delights him more than the mathematics, as this science is not only apt but also necessary to the profession of military commander." This translation from is from Firpo $(1983,123)$.

${ }^{42}$ See Biagioli (1996, 193-238).
} 
spare time, [having in mind two goals]: on the one hand, that science itself circulates as much as possible and grows; on the other hand, that the names of those excellent men, who stimulated me with their questions, are made immortal, as much as it is in my power, and that I can lead others to follow their example, to abandon the idle sloth (which is able to corrupt even the most talented) and start investigating, exchanging, and discussing serious subjects that could prove useful at some point and worth disseminating. For the time being, please, approach our efforts with a benevolent and judicious attitude.

Regards. ${ }^{43}$

This quotation shows the occasional character of the topics dealt with in Benedetti's booklets, small treatises and epistles, his concern for applied knowledge, his recognition of the importance of dissemination, as well as the celebratory intention of his publication (to render the dedicatees immortal). The epistolary collection is itself the tangible witness of a network of social relations. In a sense, Benedetti acted as a cultural ambassador for the ruling family. Although it is not possible to identify all of his correspondents, one can say with certainty that most of the epistles are tied to the northern Italian environment, specifically to Turin and Venice, but some were also directed north of the Alps. ${ }^{44}$ Many correspondents were in fact Piedmontese or Venetian patricians, courtiers, and artists linked to one of these two centers; sometimes to both, as was the case with ambassadors (e.g., Domenico Morosini, Pietro Pizzamano, and Francisco Mendoza). ${ }^{45}$

The epistles are not organized chronologically (actually the dates are almost always omitted), but according to the importance of the addressees, who might be already dead at the time of publication. The first letter was addressed to duke Emanuele Filiberto, who had already passed on, the second to his son Carlo Emanuele, and the following four letters to the powerful nobleman Andrea Provana of Leynì. The topics are linked to Benedetti's role as court mathematician and mathematical advisor. The first of the epistles is an expert report on the reform of the calendar; the second deals with a geometrical problem (the determination of the circle circumscribing a given square) that probably emerged from the lessons imparted to the prince; letters from three to six address practical problems of navigation (such as the use of astronomical instruments at sea), and so on and so forth.

\footnotetext{
${ }^{43}$ Benedetti (1585, 204, my translation): "Ad lectorem. Ut nil magis virtutis est proprium, quam agitari, et incessabili motu prodesse. Ac veluti fulgidum sydus ante oculus spectantium commicare. Ita mihi mathematicis iisque maxime philosophicis speculationibus dedito, saepissime, ut in principium summorum aulis, et amplissimis civitatibus degenti, ubi multa semper Nobilium mira curiositate, sciendi desiderio, et conferendi cupiditate referta, versantur, ingenia, contigit, modo ab his, modo ab illis, aut verbis tentari, aut literis provocari ad disserendum, de his, in quorum studiis versamur. Quarum concertationum et responsionum, quoniam non omnino indigna existimavi, quae memoria comendarentur, partem aliquam apud me conseruivi. Ubi vero per ocium licuit, relegi, ac tandem de manu mittere decrevi. Tum ut scientia ipsa quo magis diffundetur, crescat; et quicquid valeo, sine invidia in communem utilitatem conferam. Tum ut virorum praestantissimorum, qui me suis interrogationibus excitaverunt, quantum in me erit, gratitudine ergo, nomina reddam immortalia, et eorum exemplo alios, ocio sordidiore abiecto, quod solet iurialium praecipue excelsa ingenia corrumpere, ad sciscitandum conferendum, et disserendum, de rebus seriis, et quae usui aliquando esse possint, et quandoque evulgari mereantur, alliciam. Tu interim nostris laboribus fruere, et nostram diligentiam boni, et aequi consule, et Vale."

${ }^{44}$ See Mamino (1989, 429-449).

${ }^{45}$ See Cecchini and Roero (2004, 31-66).
} 
Benedetti's scientific epistles aimed not so much at exchange with other scholars as giving advice to a wide range of people beginning with the Savoy élites. There is great variety in the status and professions of the correspondents - they included mathematicians, physicians, jurists, philosophers, diplomats, experts of military art, architects, artisans, constructors of instruments and fortifications, surveyors and astrologers. ${ }^{46}$ Benedetti was not primarily concerned with establishing a connection with the Republic of Letters. Quite aristocratically, he did not regard himself and his activity as part of a learned network but rather as the center of court interactions. This center-periphery structuring of his network is emblematic of the implementation of a rising "knowledge economy," a modern bureaucratic rationalization in Weber's sense of a hierarchical organization directed by experts. ${ }^{47}$ In fact, the centralizing character of court society is mirrored by his acting as a sort of technocrat who distributed suggestions and advice from an advantaged position.

Clearly, Benedetti's social position was that of a court mathematician, a functionary acting as an expert in a wide range of realms that could fall under the compass of mathematics. Seen in this light, the mathematical formalization of practical knowledge, in particular in the realm of machine technology, engineering and architecture, corresponds to a social drive toward labor division. The division between the intellectual work of the scientific expert and that of the practitioners was essential for a progressively centralized society such as the court society. More in general, this division can be read against the background of the advance of capitalist society, in which the progressive separation of science and practice by means of labor division-later the distinction of pure and applied sciences - was the result of specialization and abstraction. As a consequence of this process, the social roots and the aims of science later escaped the self-perception of scientists themselves, as the social functions became mediated by society as a whole, in a context in which the separation secures the subordination of practical labor to the intellectual. ${ }^{48}$ In the longue durée, the scientific codification of practical knowledge occurring during the Renaissance was a step in a process of separation of theoretical knowledge and practical skills that would reach its acme in the age of the industrial revolution. ${ }^{49}$

In regards to content, the social horizon of Benedetti's scientific activity depended on the requests linked to his function as mathematician. His institutional duties immediately explain the occasional character of the themes he dealt with in his various speculations, mathematical and physical. The fragmentariness of his scientific work can be seen as a formal limitation resulting from Benedetti's courtly interactions and lack of an academic interest for systematization. He evidently did not acknowledge systematization as an epistemic value. ${ }^{50}$

\footnotetext{
${ }^{46}$ See Cecchini and Roero (2004, 31-66).

${ }^{47}$ For a stimulating Weberian treatment of institutional changes induced by bureaucratic rationalization (along with market commodification) in the early modern period, cf. Clark (2006), in particular the methodological considerations on 8-10. The reference work is Max Weber, Wirtschaft und Gesellschaft: Grundriß einer verstehenden Soziologie (1921).

${ }^{48}$ For a clear exposition of these functional aspects of science in capitalist society one can still rely on the classic of Marxist sociology from Nikolai Bukharin, "Theory and Practice from the Standpoint of Dialectical Materialism.” See Bukharin (1931, 9-33).

${ }^{49}$ Cf. Baracca et al. (1979).

${ }^{50}$ Cf. Daston and Galison on "epistemic virtues" in Objectivity (2007, 39-42). I borrow the concept to stress the rootedness of an epistemological requirement such as systematization in the social environment of the "knower." For a similar perspective, see also Kuhn (1996, 184-186).
} 
Zilsel maintained that systematization was instilled into modern science by scholastic education, which Benedetti had in fact not received. Indirectly, the social roots of his science can be traced back to the Hessenian fields of communication and transport (navigation, astronomy and geography), industry (machines technology, architecture, engineering), and war (military architecture and ballistics). All of these economic drives loom large over Benedetti's production. Ultimately, the social justification of his work rested on the economic and technological relevance of mathematics, which motivated princely support.

Benedetti's position, however, is less than half of the story. Taken in isolation, his function as a court mathematician cannot account for crucial aspects of his scientific endeavor, such as his steady engagement with philosophy and his corresponding development of a physical-mathematics at odds with Aristotelian natural philosophy. Many of the issues he dealt with directly descend from superstructural (I should say, "cultural") concerns, for instance the enhancement of mathematics at the expense of humanistic literacy and scholastic logic, or the treatment of problems specifically derived from the internal disciplinary debates in the fields of geometry, mechanics, and physics. In short, Benedetti's scientific activity was not uniquely determined by the social constraints connected with his social position but was also shaped by intellectual and political agendas. It is now time to discuss these tendencies in detail.

\section{Benedetti’s Political and Intellectual Identity: Patrizio and Philosopher}

Benedetti stemmed from the Venetian town aristocracy. As a member of the upper classes he received his education privately, outside the universities he disparaged in his early writings, and refined his culture with the frequentation of the lively intellectual circles of his hometown. His juvenilia, published in Venice- the Resolutio omnium Euclidis problematum and the Demonstratio proportionum motuum localium contra Aristotilem et omnes philosophos - show his sense of aristocratic superiority toward university professors, the "Aristotelians and philosophers" he deemed incapable of dealing with mathematics and physics. In the introduction to his first publication, he boasted of his autonomy from vulgar university teaching:
Until now I have advanced without any mentor or teacher (under the guidance of God). I have never frequented any gymnasium or school. I have not learned what the vulgar (I mean this word without arrogance) use to estimate erudition, [such as limiting it] to the time spent at school, thus setting an end to learning when the seven years [of regular studies] are ended. As long as I live, I will continue [learning]. ${ }^{51}$

As has been argued, the rejection of scholasticism was an important drive in the scientific culture of the Renaissance. In this specific case, Benedetti's criticism is not the artistengineer's protest against professorial bookish culture; rather, it pays witness to his aristocratic attitude. This attitude certainly constituted an advantage for his speculations in terms of intellectual freedom and independence from authority; however, as I stressed, this also constituted a limitation as far as systematization is concerned.

\footnotetext{
${ }^{51}$ Benedetti (1553, f. 5r).
} 
He not only distanced himself from university scholarship but also from the other major cultural tendency of his time: humanistic literacy. In the Resolutio omnium Euclidis problematum, he showed off his distaste for rhetoric, to which he opposed the simplicity and straightforwardness of mathematics.

Mathematics does not require much [stylistic] splendor. If some language expert tried to improve its elegance, this would have no value, because a change of the mathematical language and of the scientific terminology could easily confuse the sense [of the reasoning] and render everything obscure. Therefore, I will follow the scholarly tradition and use plain words in my demonstrations, as I disapprove of deceptive elegance. In this respect, I follow the steps of the ancients who taught the sciences and the subjects themselves using plain words. Petty teachers (indeed, charlatans and babblers) corrupted this manner of teaching. Although they do not understand the subject, their babbling obtains the highest praise by the vulgar who regard them as learned scholars. This should not be surprising, considering that the most perfect and distinguished expertise in the sciences is attained by very few, despite the fact that many people write a great deal in all kind of sciences and arts, babbling a lot and capturing the attention of the uneducated with illusions and bombastic words. ${ }^{52}$

The counterpoint to Benedetti's rejection of rhetoric was the limitations of his communication skills. His style reveals a want of literary training. Its dryness is far from both the Italian elegance of Galileo and the philological purity of Commandino's mathematical school of Urbino. To be sure, Benedetti's lack of any classicist reverence can account for his eclectic and creative mixing of ancient, medieval, and Renaissance approaches; however mathematical humanists did not see this as a virtue. Rather, they accused him of "impurity". This explains, at least in part, the extremely negative portrait of Benedetti by the member of the Commandino school Bernardino Baldi. In his collection of short biographies of mathematicians of all epochs, Cronica de matematici (posthumous, 1707), he stressed the profound divergence between the most exquisite scholars (più esquisiti) and Benedetti's impure approach (metodo):

The Venetian Giovanni Battista Benedetti occupied himself with mathematics, a field in which he served the dukes of Savoy. He wrote a book on gnomonic, which dealt with many proofs belonging to this discipline. However, he has been criticized by the most exquisite scholars for not having respected the method and the purity of explanation

\footnotetext{
${ }^{52}$ Benedetti (1553, f. $5 v$ ): "Adde quod Mathematicae disciplinae, neque tantum requirunt splendorem, neque si quis peritus linguarum contendat ad elegantiam rem reducere, egregium quid effecerit, quia mutato usu Mathematicae loquendi, ipsiusque scientiae terminis, sensum facile perturbaverit, et ex nihilo nihil apprehensum obtinuerit. Quare morem scholarum sequutus, obstentatione elegantiae explosa, verbis nudis in demonstrationibus usus sum, hac in parte veterum vestigia sequutus, qui nudis verbis scientias resque ipsas docebant, quem modum docendi, nobis devastarunt scioli vel potius circulatores, garruli, rebus ipsoque iudicio destituti, garrulitate siquidem apud vulgus, laudem summam consequuntur, et pro doctis circunferuntur, nec mirum, cum scientiarum perfecta exquisitaque perita, paucissimis detur, non obstante quod multi permulta de omnis generis et scientiis et artibus scribant, permultaque garriant, fucis suis, et ampullis imperitorum oculos perstringentes $[\ldots] . "$
} 
which mathematics requires and which was respected by the Greek masters and by their followers. He also wrote some light things, of no great import. ${ }^{53}$

The (mathematical) philosopher-Benedetti's self-presentation as an opponent of scholasticism, on the one hand, and of humanistic literacy, on the other, did not result in a corporate identity as practical mathematician, or engineer. In learned controversies, Benedetti showed the power of his mathematical approach and demonstrated it through philosophy. Accordingly, he presented himself as a philosopher and, in order to substantiate his claim, he was forced to enter the cultural arena of philosophical controversy and construct his own identity as a mathematical philosopher. This meant openly defending the epistemological status of mathematics. He went so far as to claim for this discipline a rank higher than Aristotelian natural philosophy, metaphysics, and ethics owing to the certainty of its demonstrations. Thus he tackled the issue De philosophia mathematica (On Mathematical Philosophy) in a letter to the Venetian patrizio, Domenico Pisani:

I am surprised that, although you are well versed in Aristotelian philosophy, nonetheless you make a distinction between the philosopher and the mathematician in your writings, as if the mathematician were not as much a philosopher as the naturalist and the metaphysician. In fact, as far as the certainty of his conclusions is concerned, he deserves the title of philosopher much more than them. ${ }^{54}$

This reference to the certainty of mathematical reasoning bears witness to Benedetti's acquaintance with the ongoing methodological controversy over the dignity of mathematics and its validity. He agreed with his correspondent, the Padua professor Pietro Catena, that mathematical certainty has an intelligible character. ${ }^{55}$ As he wrote to Pisani,

Actually, you are not the only one who makes this mistake, but this is graver in consideration of the fact that although you [Aristotelians] even label ethics as a philosophical discipline, you do not acknowledge that the divine mathematical sciences also should be adorned with the name of philosophy. In fact, if we consider this name more attentively we will clearly see that it is in itself more suited to the mathematician than to anyone else, since none of the others is more certain in his affirmations than the mathematician. And no one is more driven by the love of science in his cognition. This is evident. In fact, [the mathematician] does not rely on the senses nor accepts any presupposition that is not so true and evident to the intellect that no power whatsoever could show that it is false. ${ }^{56}$

\footnotetext{
${ }^{53}$ Baldi $(1707,140)$ : “GIO[VANNI] BATTISTA Benedetti veneziano attese alle matematiche, nelle quali servì i Duchi di Savoia. Scrisse un libro di gnomonica, il quale toccò molte cose appartenenti alle dimostrazioni della detta disciplina, se non che viene ripreso da più esquisiti di non haver'osservato quel metodo, e quella purità dell'insegnare, che ricercano le matematiche, et è stato osservato dagl'ottimi Greci, e dagl'imitatori loro. Scrisse anco alcune altre cose leggiere, e di nessun momento."

${ }^{54}$ Bendetti (1585, 298): "Miror quod cum in Aristotele sis versatus, in tuis tamen scriptis philosophum a Mathematico separes, quasi mathematicus non sit adeo philosophus, ut est naturalis, et metaphysicus, cum multo magis quam ii philosophus sit appellandus, si ad veritatem suarum conclusionum respiciamus."

${ }^{55}$ Cf. De Pace (1993, 228-229).

${ }^{56}$ Bendetti $(1585,298)$ : "Verum quidem est, te in huiusmodi errore solum non versari; sed gravius est, quod cum vos videatis etiam res morales sub philosophiae appellationem cadere, non animadvertatis divinas scientias mathematicas etiam philosophiae nomine ornandas esse. Quod si eiusdem nomen penitius considerare velimus,
} 
During the Renaissance, mathematical philosophy was connected by definition to the reassessment of Pythagoreanism, no matter how controversial, ambiguous, and deprived of direct sources this reappraisal was. On his adherence to Pythagorean views, Benedetti mockingly wrote to the Savoy courtier, Paolo Capra: "If the souls' transmigration imagined by the father of Italian wisdom, Pythagoras, were true, I believe that your soul and mine were once the souls of hunting dogs. ${ }^{~} 57$ At that time Copernicus's planetary system also counted as a Pythagorean invention. ${ }^{58}$ Benedetti explicitly praised Pythagoras's discoveries in astronomy in the letter to the reader opening the Diversae speculationes, as an anticipation of his treatment of the Copernican system. Benedetti expands on cosmology in the (antiAristotelian) philosophical section of the work, the fourth book entitled Disputationes de quibusdam placitis Arist [otelis]. ${ }^{59} \mathrm{He}$ also defended the Pythagorean doctrine of the music produced by the celestial bodies against Aristotelian criticism, by interpreting this doctrine not as a reference to the production of physical sounds but rather to mathematical harmony introduced into the world by the Divine Providence. ${ }^{60}$

In the same book of the Diversae speculationes, Benedetti detailed his criticism of Aristotelian natural philosophy. He first developed an alternative mathematical and atomistic theory of motion, asserting against Aristotle that void is necessary to local motion. He analyzed downward and upward motions in different media making use of the Archimedean concept of buoyancy to account for the dependence of vertical motions, in particular free fall, on the specific weight of the bodies rather than an absolute weight; he employed the (Euclidean) theory of proportions to interrelate the velocities, volumes, and surfaces of moving bodies; moreover, he clarified his basic natural conceptions on issues such as the existence of void, the definition of space and time, and the attainability of actual infinity in nature; he rejected Aristotle's theory of natural places and reflected on the connection of postCopernican astronomy with physics, defending heterodox views such as the infinity of space and the plurality of worlds, specifically equating the Earth to the other planets of the solar system. ${ }^{61}$ Benedetti's rejection of key elements of Aristotle's Physics was certainly acute and his revision of crucial concepts of natural philosophy was in line with the most original trends of the Italian Renaissance. However, his endeavor remained limited: his capacity to demolish well-established physical views and to solve specific problems was not accompanied by the implementation of a unitary vision. In this respect, scholastically trained contemporaries of his proved much more efficient in the pars construens, embodied by monuments of natural philosophy such as Bernardino Telesio's De rerum natura (1565, 1570 and 1586), Giordano

\footnotetext{
inveniemus aperte, mathematico magis illud ipsum quam cuilibet alio convenire, cum nullus ex aliis tam certo sciat id quem affirmat quam mathematicus, neque aliquis sit, qui in cognitionis, et scientiae cupiditatem magis ducantur, ut aperte patet, cum nec etiam ipsi sensui det locum, neque aliquid praesupponat, quem non sit ita verum et intellectui notum, ut nulla quaevis potentia, illud esse falsum ostendere queat."

${ }^{57}$ Ibid., 285: "Si vera esset animorum illa transmigratio quam sibi Italicae sapientiae Pater Pythagoras effinxerat; tuam, meanque existimarem animam canis, quandoque venatici fuisse."

${ }^{58} \mathrm{See}$ "The Invention of the Pythagorean Cosmology" (Omodeo 2014a, 167-170).

${ }^{59}$ Bendetti (1585, f. A3v). On his cosmology, see Di Bono (1987, 283-300), and Omodeo (2009).

${ }^{60}$ Bendetti (1585, 190-191): "Pythagoreorum opinionem de sonitu corporum coelestium non fuisse ab Aristotele sublatam."

${ }^{61}$ For a detailed discussion of Benedetti's foundations of physics, see Omodeo and Renn, Science in Court Society (in press), ch. 7.
} 
Bruno's Italian dialogues (1584-1585) and Frankfurt poems (1591), or Francesco Patrizi's Nova de universis philosophia (1591).

The Courtier - As a young independent intellectual, Benedetti wrote in a harshly polemical tone, accusing his opponents of slavishly following the authority of their master, Aristotle, instead of relying on solid arguments based on mathematics and experience. ${ }^{62}$ Later, as a courtier in Turin, he realized that controversies with other scholars belonging to the town élite should not escalate and he became more moderate. Benedetti's anti-Aristotelian views were thus softened by courtly etiquette. He was part of the circle of intellectuals gathering around the duke, which the professor of jurisprudence and Benedetti's correspondent, Bernardo Trotto depicted as follows:

These learned men, played by the Prince like well-tuned musical instruments, immediately give out their specific sounds with words. And they give it their best to be clearly understood in conversations, to please the others with good arguments and to convince them of their opinions. It is like the consonance of truth. In fact, everyone says what one knows or, at least, considers to be true. Hence they discuss natural issues and at times moral ones and mathematical ones. In conclusion, one can regard him [the prince] as Apollo surrounded by the Muses by the water spring that was originated by a foot hit of the winged horse. ${ }^{63}$

Benedetti entered courtly conversations on the most varied issues and confronted Aristotelian views defended, among others, by the court physician Giovan Francesco Arma, or university professors such as the philosopher, Antonio Berga. In informal and polite meetings, Benedetti frankly expressed his views and objections. Although divergences of opinions emerged, education always prevailed over intellectual disagreement.

This genteel climate can best be captured by publications such as Arma's report to Emanuele Filiberto about a discussion on meteorological problems that took place between prince Carlo Emanuele, Benedetti, the professor of mathematics, Francesco Ottonaio, Berga and himself during the prince's meal for three consecutive days. The report, printed in 1580 under the title Proposte tenute co'l Serenissimo Prencipe (Issues Discussed with the Very Serene Prince), had the form of a poem. To get an idea of the tenor and the contents of such

\footnotetext{
${ }^{62}$ In the preface to the second edition of the Demonstratio proportionum motum localium (1555), Benedetti wrote (my translation): "They could not concede that Aristotle was mistaken in any way, because they do not regard him as a human being. Rather, they confer upon him the celestial condition of a pagan divinity. And they see even slight disagreement as a sin. Therefore [they believe that] I committed (and still commit) heresy if, according to their judgment, I do not follow the pure and authentic mind of Aristotle's doctrine in any manner." For the original text, see Benedetti's original text in Maccagni (1967, 21): "Ne vero Aristotelem ullo modo errasse concederent, cum illum non infra humanae conditionis terminum habeant, sed potius veluti coeleste quoddam numen sibi proponant, censeantque nefas esse si vel latum quidem unguem ab eo quis dissentiat, in hac potius haeresi fuisse, ac etiamnum esse, ut me germanum et genuinum sensum Aristotelicae opinionis nequaquam ex authoris mente assecutum existiment."

${ }^{63}$ Trotto $(1625,2-3)$ : “[...] questi huomini saputi, tocchi dal Prencipe, come instrumenti musici bene accordati, subito rendono ciascuno il suo suono con le parole et quanto meglio possono procurare d'essere intesi discorrendo, e di dar diletto con le buone ragioni, et anco di tirare gli altri al suo parere, come ad una consonanza della verità: perché ognuno dice quello ch'egli sa o crede almeno sia vero. E quindi si veggono trattare hor cose naturali, hor morali, hor mathematiche. Sì che egli quasi come uno Apolline si può dire, che sta fra le Muse, intorno al fonte, che uscì dal colpo del piede del cavallo alato."
} 
courtly conversations one could consider a quarrel over the 'solar attraction' of terrestrial elements that opposed Arma to Benedetti, Berga and Ottonaio:

The day after [the second day], Mister Benedetti

And Mister Berga, along with Ottonaio

Expressed opinions that are far from mine:

That the Sun attracts everything to itself with its great brightness.

As if it had hands. ${ }^{64}$

Arma objected that the thesis that the Sun attracts other bodies would have disruptive consequences for the solari, the inhabitants of the Sun. The reader apprehends that Benedetti agreed with him on this remark, but no further details are provided. Ottonaio mentioned the vapors brought upward by the Sun's action. Following the associations of ideas, the next dinner table topic concerned natural places and elemental displacements, with special reference to the motion of vapors. On the third day, prince Carlo Emanuele asked his learned tutors for an explanation of the origin of lightning, and why we perceive the light before the thunder. Arma's physiological answer was that our sight is quicker than our hearing was received with skepticism by his colleagues. However, no details of the discussion are reported except that they concerned the theory of perception, light, and optics. At the end of the three days, Arma wrote down all opinions for duke Emanuele Filiberto and all courtiers confirmed the reliability of the poetic report:

All of this was presented in written form

To His Highness, reporting all speeches.

Dr Berga confirmed it [the rightness of the report].

Benedetti did the same.

After that we discussed other issues,

Hidden things and their effects. ${ }^{65}$

Other publications from those years mention similar courtly conversations taking place at table. For instance, the university professor of philosophy and medicine, Agostino Bucci reported in the preface to his medical book Disputatio de principatu partium corporis (Disputation on the Superiority of Parts of the Body) (1583) on a physiological controversy that was sparked off by his anatomical theories. Carlo Emanuele gathered his learned courtiers to discuss vexed Aristotelian-Galenic questions concerning the 'superiority' of the heart or of the brain, and the location of the soul in the body. The participants were not only physicians, as Bucci also mentions two 'mathematicians,' Ottonaio and Benedetti. ${ }^{66}$

The complaisant tone of courtly controversies signals the esprit de corps of the Savoy cultural élites prevailing over intellectual disagreements and creating a climate of polite openmindedness. However, as soon as the reputation of the scientific intelligentsia was attacked

\footnotetext{
${ }^{64}$ See Arma (1580, f. A2v): “Il Signor Benedetti l'indomani/ Col signor Berga, insiem' a l'Ottonaglio/ Forn'in pensier' a me d'assai lontani,/ Che'l Sol tirass'a sé com grand'abbagio/ Ogni cosa si com'havesse mani."

${ }^{65}$ Arma (1580., f. A4r): "E tutto quest'in scritti fu donato/ A Sua Altezza, con tutti soi detti./ E fu dal Dottor Berga conformato./ Il che fece'l signore Benedetti./Fu poi d'altre proposte ragionato/ E de gl'occolte cose, e soi effetti."

${ }^{66}$ Bucci (1583, 7-8). Cf. Mammola (2013, 6-8).
} 
from outside the court and the academic institutions, moderation gave way to the crudest polemics. In 1578, the court physician Arma was the target of a denigrating pamphlet in twenty points, composed by an anonymous author criticizing his views on the comet of 15771578. A harsh polemic thus started in which none of the parties renounced personal offences and insults, which went far beyond the subject matter, as is documented by an apology for Arma penned by Monsignor Della Torre, Difesa de la $\pi \omega \gamma \omega v i$ a d'il Dottore Arma (Defense of the Bearded Comet by Dr. Arma). The author, who was linked to the court, published his pamphlet under the pseudonym of 'filosofo stravagante' (extravagant philosopher). ${ }^{67}$ Benedetti himself had to defend astrological prognostications cast for the court against the attacks of Benedetto Altavilla, a critic of the reliability of astronomical calculation from Vicenza. In his corrosive response, he singled out the mathematical shortcomings of his opponent and disqualified him. Benedetti's polemical writing appeared first in Italian in the form of a public letter to the jurisprudent Trotto, Lettera per modo di discorso... intorno ad alcune nuove riprensioni, et emendationi, contra alli calculatori delle effemeridi (Letter in the Form of a Discourse... on Recent Criticism and Corrections against Ephemerides Calculations) (Turin, 1581). A Latin translation, as Defensio ephemeridum (A Defense of Ephemerides), was later included among the epistles of the Diversae speculationes. ${ }^{6}$

The Savoy Intellectual - The participation in courtly life required adherence to the hegemonic project of the ruling family in a period of transition from feudal society to centralized state administration. In Benedetti's case, the supervision and advice on technical matters was not only functional in regards to socio-economic needs; it also contributed to the establishment of the court as a cultural center. With respect to the cultural hegemony of the court, patronage, education and cultural diplomacy deserve particular mention. In all of these realms, Benedetti was actively engaged.

Political issues directly informed some of Benedetti's scientific writings, for instance the first of the scientific epistles of Diversae speculationes dealing with the calendar reform promoted by the Pope. The problem was not merely a technical one as it concerned Catholic hegemony in Europe in a time of confessional divides and clashes. Benedetti's awareness of the importance of this issue is reflected in his decision to sign his contribution on this matter, which had first appeared in 1578 as De temporum emendatione opinio, neither as a mathematician nor as a philosopher but as patritius Venetus, thus stressing his noble origin. Another instance of politically informed writings are his epistles on navigation instruments and techniques addressed to Provana, the aristocrat entrusted with the command of the Savoy ships in the battle of Lepanto.

Moreover, Benedetti contributed to courtly diplomacy by interacting with scholars and courtiers. He also assessed the quality of mathematical works dedicated to the dukes. As appears from his correspondence with Patrizi, he mediated between the famous Ferrara philosopher - and professor-to-be of Platonic philosophy at the Sapienza in Rome - and the dukes, on the occasion of the dedication of Della nuova geometria libri XV (Fifteen Books on

\footnotetext{
${ }^{67}$ Omodeo (2008).

${ }^{68}$ Omodeo (2014a, 142-149) and Omodeo (2014b).
} 
the New Geometry) (Ferrara, 1587) to Carlo Emanuele. Patrizi expressed his gratitude to Benedetti for handling on a copy to his patron (letter from Ferrara, 6 April 1587):

Very Magnificent and Excellent Mister,

I rejoice with your Lordship that you recovered from sickness quicker than believed. And I am very thankful to you for presenting my book to the very serene Prince and promising to inform me about his remarks after he has read it. If by chance the book will be forgotten, due to his many duties [negozii], I hope at least that you will remember me. If his High Serenity will give some sign that he appreciated it [my book], I will be very glad and I will be particularly grateful to your Lordship for your benevolence. ${ }^{69}$

In exchange, Benedetti sent to Patrizi a copy of his discussion on the relative sizes of the elements of the earth and of the water. ${ }^{70}$

Patronage of the sciences and the arts played a role in the construction of cultural hegemony in the age of court society. Turin was visited by the most celebrated poets of the time, in particular Torquato Tasso in 1578-1579, and Giovan Battista Marino in 1608-1615. ${ }^{71}$ Benedetti, for his part, contributed to the reputation of the dukes as an acknowledged scientist. The leading mathematician and astronomer of the Collegio Romano, Christopher Clavius, extolled his merits in a eulogy for the Savoy family, in the 1589 edition of his commentary of Euclid's Elements. In the dedicatory epistle, directed to Carlo Emanuele, he called Benedetti a "scientissimus rerum Mathematicarum" (very expert scholar in mathematics). ${ }^{72}$ Benedetti himself dedicated his most significant publications to his patrons. Overall, the Diversae speculationes had an celebratory intent. It appeared in a series of elegant volumes extolling the magnificence of the court and Savoy, such as the court historian Emanuele Filiberto Pingone's Augusta Taurinorum (1577), a celebration of the capital, Inclytorum Saxoniae Sabaudiaeque principum arbor gentilitia (1581), on the rulers' lineage, and Sindon evangelica (1581), on Christ's shroud, recently transferred from Chambéry to Turin. The Diversae speculationes made the proficiency of the court intellectual, Benedetti, and his mathematical skills publicly visible. It also bore witness to the intensity of the cultural debates going on in Turin or connected with other centers. Its miscellaneous and epistolary form was suitable for displaying the variety of Benedetti's interests and for praising his patrons, supporters, friends, and colleagues as they were named one by one as dedicatees and addressees of the sections and letters.

Education was another pivotal element in Savoy cultural politics. Emanuele Filiberto did not leave too much room for ecclesiastical educators such as the Jesuits, who were in that time the major advocates for a religiously conformist formation in Catholic countries. The dukes' choice of lay tutors for his offspring, namely Benedetti and the mathematician

\footnotetext{
${ }^{69}$ Patrizi (1975, n. XXVII, 53): "Molto Magnifico et Eccellentissimo Signore, mi rallegro con Vostra Signoria, che più tosto che non credea si è rilevata dal male, e li rendo moltissime gratie dell'haver presentato il mio libro a quel Serenissimo Prencipe, e ricevuto il favore, che Ella mi avvisi ciò che haverà detto, dopo che l'havrà letto. Et se per sorte per li molti negozii il libro andasse in oblio, spero da Lei il rimedio di un poco di ricordanza, la quale, se partorirà alcun segno che Sua Altezza Serenissima l'habbia havuto caro, mi sarà carissimo e tutto l'obbligo l'haverò a Vostra Signoria e all'amor suo verso me."

${ }^{70}$ Patrizi to Benedetti (Ferrara, 18 January 1588), Patrizi (1975, n. XXX, 57-58).

71 See Doglio $(1998,621,625)$.

72 See Clavius 1589 , ff. $* 4 r-* 5 r$.
} 
Bartolomeo Cristini after him, is indicative of a political choice representing intellectual independence. The same desire for political autonomy applies to the dukes' university politics in a time in which the most contested field of post-Tridentine confessional and cultural struggles was academia. At an international level, the Jesuits proved the most engaged confessional group capable of implementing a religiously conformist educational system. ${ }^{73}$ When Emanuele Filiberto reopened the Savoy university, first in Mondovì (1560) and later in Turin 1566), the Jesuits immediately opened colleges in both towns. Leading Jesuit intellectuals such as Antonio Possevino and Roberto Bellarmino were sent to Piedmont - a territory "dangerously" close to Calvinist Switzerland in the eyes of the Roman authorities. Initially, Emanuele Filiberto supported the Jesuits and let them occupy the chair of grammar at the expense of the renowned humanist Giovanni Battista Giraldi Cinzio of Ferrara, and almost accorded them nine chairs. However, the project did not succeed. It was met with fierce opposition by the town and the university, who thought their autonomy was being menaced. ${ }^{74}$ Emanuele Filiberto himself changed his mind as his trust in the Jesuits fluctuated, just as his relations with Rome did. These relations were especially stained by the Cavour edict of tolerance, delivered in 1561, which guaranteed the religious freedom of his protestant subjects in the Alps. The promulgation provoked vehement protests from Rome, as well as the appointment of the intransigent Cardinal Inquisitor, Michele Ghisleri, to the diocese of Alexandria as Bishop of Mondovì, with the aim of reinforcing religious conformity. The relations between this champion of orthodoxy and the pragmatic politics of the Savoy dukes were tense, including after Ghisleri was elected pontiff as Pius V in 1566. The political issue of the independency of Savoy from excessive pontifical interference must have affected Emanuele Filiberto's decision to exclude the Jesuits from the university and the reintroduction of the teaching of humanities. Ultimately, the reasons for the defense of university autonomy in Turin are similar to those concurrently discussed at the Sorbonne and Padua. The loyalty of public teaching institutions to the King of France and to Venice, respectively, seemed to be better secured by marginalizing or even banning the Jesuits, as they were seen as direct representatives of papal interests. ${ }^{75}$

There is indirect evidence that Benedetti sided with the humanists in their criticism of the Jesuits. Patrizi, who belonged to the same Ferrara cultural environment as Giraldi Cinzio (the professor removed to make room for the Jesuits), asked Benedetti's support for the candidacy of his friend Giovanni Giacomo Orgiazzo for the position of professor of humanities in $1583 .^{76}$ The same epistle bears witness to the fact that Benedetti advised the dukes in matters concerning university policy. The sixteenth-century biographer of Emanuele Filiberto, Giovanni Tonso, even included Benedetti among those who made the University of

\footnotetext{
${ }^{73}$ The case of the German Empire, where the Jesuits virtually obtained the monopoly of university teaching in Catholic countries, is telling. See Hellyer (2005). A thoughtful study on the political rationale behind the establishment of Jesuit education in an age of Konfessionalisierung and the wars of religion is found in Gui (1989).

${ }^{74}$ See Grendler $(2002,42-44)$.

${ }^{75}$ Cf. my essay "Torino, 1593: Motivi dell'opposizione universitaria ai gesuiti nel contesto degli antagonismi europei del tempo," Omodeo (2014c).

${ }^{76}$ Patrizi to Benedetti (Ferrara, 21 March 1583) in Patrizi $(1975,39)$.
} 
Turin eminent (Qui viri insignes publice docuerint) ${ }^{77}$ Another contemporary of Benedetti, the mathematician Cristini, mentioned him as one of those whom Emanuele Filiberto recruited in order to increase the prestige of his university. ${ }^{78}$ Still, the role he played in the academic life of Turin remains obscure due to the lack of documentary evidence. ${ }^{79}$

Another indicator of Benedetti's attitude toward the Counter-reformation and the confessional quarrels of his time emerges from his approach to the calendar reform, in a time in which the pope's political and religious legitimacy and his authority in such matters was cast into doubt by many, especially in the reformed countries. The elimination of ten days to make the spring equinox date correspond to its date at the time of the Council of Nicea was controversial, since it symbolically legitimized the universality of the Roman Church through Constantine. Benedetti wrote the aforementioned reform proposal on 1 April 1578 and Emanuele Filiberto sent it to Rome on 31 May. The most striking feature of Benedetti's proposal is its technical radicalism and extreme rationalism. August Ziggelaar's perspicuous description of Benedetti's proposal went as follows: "Benedetti prefers the Eastern date to be fixed according to the true motions of Sun and Moon rather than by cycles. He finds that the Prutenic tables are sufficiently exact for this purpose. Furthermore not ten days, not even fourteen, but twenty-one days should be left out in order to make the first day of January the winter solstice. The lengths of the months are to be adjusted so that they coincide with the presence of the Sun in each of the twelve zodiacal signs. Surely, these time intervals change their lengths in the course of time because of the motion of the perihelion of the Earth, but Benedetti assures us that only after 24,000 years will an adjustment be necessary. The proposal is not only interesting and original, but also very rational because, by eliminating all reference to the Moon, it makes the year entirely solar." ${ }^{80}$ The extreme technicality of such a proposal, one can argue, was also a means to de-ideologize the issue. Therefore, it was not only rejected for its "scientific radicalism" but also for its rationalistic distance from confessional struggles. This positioning is in line with late-humanistic universalism and signals Benedetti's distance from the Counter-reformation and the militant cultural production of those years. ${ }^{81} \mathrm{He}$ can be seen as an organic intellectual of the Savoy ruling class who adhered to a political project, which included self-rule in matters of culture and education.

\section{Conclusive Remarks and Prospects for Future Research}

I have distinguished the social and the political-cultural coordinates of Benedetti's science and treated them separately. On the one hand, his position as a court mathematician directly determined much of the content of his writings, occasioned by the requests addressed to him

\footnotetext{
77 See Tonso (1596, 141): "Neque vero liberalium disciplinarum omniumque artium colendarum quam susceperat cogitationem unquam deposuit: nam et publicum earum Gymnasium pro tempore in oppido Monteregali instituit: et qui viri in quacunque scientia excellerent undique conquisuit. [...] Mathematicos illustres Franciscum Othonarium, et Io. Baptistam Benedictum Venetum.”

${ }^{78}$ Bordiga derived this information from a manuscript of Cristini's preserved in the Biblioteca Marciana in Venice. See Bordiga (1985, 596-597).

${ }^{79}$ The historian of Piedmontese Universities Silvio Pivano already complained in the 1920s about the lack of relevant documents. See Pivano (1928, 19-22).

${ }^{80}$ See Ziggelaar $(1983,211,214)$.

81 See Steinmetz (2010). For an insightful study on cultural production in the time of European confessionalization, see Mulsow (2007).
} 
as a court expert in technical issues pertaining to mathematics. His position also determined formal aspects of his work, in particular its occasional character and fragmentariness. On the other hand, Benedetti's identity as a philosopher directly related to his cultural ambitions and his engagement aimed to affirm mathematical philosophy in the intellectual arena against scholastic thinkers and humanistic literati. His political identity as a lay aristocrat made him an organic part of the centralizing project of the court and marked his distance from counterreformist drives which sought to impose Roman universal interests over territorial states' autonomy. His support for a sort of party of the politiques resulted in treatises advising on politically relevant technical and cultural issues (e.g., navigation on the occasion of the battle of Lepanto or the calendar reform). His activity as a lay educator (e.g, his arithmetic teaching to the prince, Carlo Emanuele) is found in his pedagogical writings, some of which were published in his scientific miscellanea. In summary, both content and form, as well as the demarcation of the fields of his scientific competence as a mathematician and philosopher, depended on social settings and cultural engagement.

The analytical distinction between position and identity, between the mathematician and the philosopher, should not be taken rigidly. Retaking the initial quotation from Gramsci, it is necessary to stress the analytical usefulness of the distinction but also the limitation of a net separation of the two realms as "the material forces cannot be historically conceived without any forms and the ideologies would be individual whims separated from the material forces." In this case, the hylemorphic image, derived from Aristotelian philosophical terminology, should not be taken literally, as to imply some sort of subordination or dichotomy. Quite on the contrary, it helps stressing the interconnection, interdependency and interpenetration of the socio-economical realm (here indicated as the material pole) and the cultural (as the formal pole). At the same time, the acknowledgment of the importance of both poles serves to avoid renouncing structural and economic considerations, as has become common after the cultural turn of the Eighties.

Take for instance Benedetti's mathematical formalism. This can be accounted for structurally in functional terms of specialization and social control by means of labor division. As a court mathematician, he had to supervise engineering works carried out for the state. At the same time, mathematical formalism played a cultural role not only as an approach to nature but to the most varied issues that could be of interest to the court, including literature. ${ }^{82}$ It even became a matter of style, distinguished from scholastic syllogistic and humanistic verbosity. In summary, only by taking into account both poles can one form a complete and not reductive image of Benedetti's science.

To summarize the most evident features of Benedetti's endeavors resulting from this interpenetration of elements and drives, it was courtly, secular, anti-Academic, unsystematic, occasional, elitist, learned, abstract, pleasant and useful. It was secular, that is, non theological, as it was linked to the interests of the ruling class and the state. It was a useful and pleasant science: on the one hand, it was practice-oriented but not purely empirical; on the other hand, it proved witty and fit for courtly sociability. It was abstract and disinterested: superior to the vulgar and tuned to aristocratic values. Learned: fit to be exhibited at court alongside the other arts. Elitist: Benedetti elevated mathematics from a practical discipline of

\footnotetext{
${ }^{82}$ See Omodeo (2012).
} 
scientist-engineers to a refined cultural activity. Occasional: linked to the variegate political and cultural interests of the court. Unsystematic: fragmented, lacking the inner coherence of scholasticism. Anti-Academic: free from concerns about respect for university scholarly traditions. The courtly character of Benedetti's science was at once its strength and its weakness: it was technical and abstract without losing contact with practice and experiencea mathematical-empirical science in nuce; it was (relatively) free from bookish tradition and theology but not from the contingencies of courtly life.

The fact that Benedetti never established a scientific school around himself can be seen as an indicator of the precariousness of patronized science, linked to the person of a particular ruler and not institutionalized at the level of an academic body. In the course of the seventeenth century these limitations of early court society would be solved by securing scientific continuity for patronized science through the foundation of scientific societies. These constituted an improvement over the volatility of Renaissance patronage, depending on the humors and interests of a prince, by substituting him for a corporative persona ficta deputed to protect, credit, and promote science (Biagioli $(1995,1418)$. This did not imply a diminution of the political relevance of science. As has been argued, the institution of the Académie Royale des Sciences as a means to patronize all of the sciences at once meant the conquest of a new kingdom, la république des lettres tout entière, for Louis XIV (Biagioli $(1995,1438)$.

The meaning of Benedetti's contribution to science, however, cannot be grasped at a micro-historical level, just as the history of Savoy cannot be merely explained in terms of internal developments considered in isolation from geopolitical and longue durée perspectives. A better understanding of his case will require a wider reconstruction of the socio-economic settings as well as the cultural-political drives of science in the passage from the Middle Ages to modernity. This broader picture should capture the interests of the emerging urban and merchant groups, as a factor that made the value of technological advance recognizable. In turn, the acknowledgment of the social and theoretical value of practical experience led to its codification in various fields, including the science of machines. The Verwissenschaftichung of this field-its formalization in mathematical terms and its systematization - could not have occurred without philosophy, that is, without reassessing and transforming the conceptual tools and methods of scholasticism and humanism. Thus, the study of early modern science needs a twofold investigation of its social conditions and its cultural significance, at various levels of analysis-economic, social, technological, institutional, theological, philosophical, and political.

Historians of mechanics have already studied some junctions of the socio-political context with particular care, especially the combination of mechanics with technology and practice. However, the general framework, that of the dynamic connection between economic structures and cultural-political action, requires further investigation. I would refer to this overarching issue in Gramscian terms as the problematic of the "historical bloc," that is, the historical intertwining of social-economic necessity and ethical-political freedom. During the sixteenth and early-seventeenth centuries when a great transformation took place toward a market society, the socio-political bloc was realized as an alliance between the productionand-market interests of early capitalist classes and the aristocracy in the framework of 
emerging national states (also their preformation: the court-centered territorial states). ${ }^{83}$ The manner in which this economic-political bloc fostered technological advance and science requires specific investigation. One should take into account state-directed investments in economy, technological projects and science, and the foundation of national academies. JeanBaptiste Colbert's action in the time of the Roy-Soleil Louis XIV is an illuminating instance of scientific and economic politics occurring under the hegemony of a centralized national monarchy; while the Netherlands in the seventeenth century offers a suitable terrain for an analysis of the concomitant flowering of natural sciences and capitalistic entrepreneurship under the acknowledged leadership of the bourgeois classes of bankers and merchants. ${ }^{84}$

The cultural dimension of early modern science, beginning with mechanics, has to be understood as politically mediated by religion and philosophy. Famously, the natural questions brought up by the science of machines and its development into a general physica was at the center of philosophical and theological clashes, relative both to the scientific status of new fields of natural inquiry and their frame of comprehension. The polemics between mechanistic philosophers à la Descartes and defenders of the scholastic tradition during the seventeenth century is revealing of wider cultural struggles about models of society and epistemic values. Should the inquiry into the book of nature be pursued independently from the letters of the Holy Scriptures? How should experimentation and metaphysics relate to each other? Would not accepting scientific autonomy imply renouncing the centrality of religion in society? These are typical and unavoidable questions and doubts posed to early modern scientists in the time of the most severe conflict between science and religion in the history of the Latin West marked by the Roman censure of the Copernican system and the condemnation of Galileo. Several intellectuals attempted to reconcile philosophical and religious positions by developing experimental programs 'renouncing all hypotheses' - as typically occurred in state-patronized scientific academies. Continuous negotiation of the realms of jurisdiction of states, churches, and economic actors determined the various degrees of autonomy that could be accorded-or denied-to natural inquiry. At a concrete institutional level, the balance of relative forces among the different cultural parties determined the degree of autonomy that was accorded, in various places, to education and research, to schools, universities, and academies. Hegemonic struggles concerned the values that should inform teaching centers and scientific institutions, affected the strictness of the imposition and informed curricula and research programs.

\footnotetext{
${ }^{83}$ A case in point would be mercantilism. Karl Polanyi, in his valuable reconstruction of the historical premises of the market society and free market ideology on the correlation and interaction between politics and economy in the constitution of nineteenth century liberalism, has pointed out that the tension, in early modern Great Britain, between the economic interests of those benefiting from the enclosures and the social interests of the pauperized people resulted in political regulation. This determined the pace of the socio-economic transformation that would eventually lead to the Industrial Revolution and made the process sustainable by diluting its disruptive effects. See Polanyi $(2001,35-40)$, whose main concern was to present an insightful case for government playing a central role in modern economic life. Cf. Polanyi (2001, 40): "England withstood without grave damage the calamity of the enclosures only because the Tudors and the earl Stuarts used the power of the Crown to slow down the process of economic improvement until it became socially bearable-employing the power of the central government to relieve the victims of the transformation, and attempting to canalize the process of change so as to make its course less devastating."

${ }^{84}$ For the relation between princely patrons and academies see, among others, Biagioli (1995, 1417-1453). On early capitalist Netherlands and science, cf. Cook (2007).
} 
As a conclusion, I should advance, at least tentatively, an assessment of the historical position of Benedetti's mechanics in the history of modern science. The most evident feature of his science was the connection of mechanics with a wide array of fields, including cosmology, natural philosophy, and epistemology. This interweaving has escaped scholars who too narrowly dealt with Benedetti's technical achievement by ahistorically insulating his mechanics from its conceptual network, neglecting its interdisciplinary ties and the social motivations underlying it. ${ }^{85}$ His integrative view on mechanics might seem blurred, as its borders are not clear-cut. This remarkable variety leads us back to the question derived from Lagrange's ex-post historical views on the developments of mechanics: the question of demarcation as a historical problem. Briefly, this is the problem of the emergence of a scientific field. With the help of Lagrange I have distinguished three phases of the historical development of early modern mechanics: from the science of machines to a physicalmathematical science of balance and motion and, finally, an analytical science. Although Benedetti's work can be located at the threshold of the emergence of a general physicalmathematical discipline, his work shows elements of all three phases. It explicitly maintains the connection with technology but clearly indicates the later development of physical generalization and mathematical formalism. I argue that it was precisely the inhomogeneity of his conceptions, the merging of social and cognitive dimensions, of technological and philosophical concerns, of disciplinary and political interests that made his work at once blurred and productive. Benedetti is representative of an age, in which the daring connection of mathematical and philosophical speculations, his crossing of social and epistemological barriers, opened up a space of possibility for a new mathematical physics. Multidirectional connections, in particular between experience and theory, technology and philosophy, were a necessary condition for the transformation of an artist-engineers' science of machines to the scientist-engineers' science of balance and motion and, later, for its elevation to a universal knowledge of the mathematical principles of nature.

\section{References}

Arma, Francesco. 1580. Queste sono parti delle propposte tenute col Serenis. Prencipe nostro. Torino: Appresso gli heredi del Bevilacqua.

Axworthy, Angela. 2016. Les mathématiques et la science. In Le Methématicien renaissant et son savoir. Le Statut des mathématiques selon Oronce Fine, 83 ff. Paris: Classique Garnier.

Baldi, Bernardino. 1707. Cronica de matematici overo epitome dell'istoria delle vite loro. Urbino: Per Angelo Ant. Monticelli.

Baracca, Angelo, Stefano Ruffo and Arturo Russo. 1979. Scienza e industria (1848-1915): Gli sviluppi scientifici connessi alla seconda rivoluzione industriale. Roma-Bari: Laterza.

\footnotetext{
${ }^{85}$ An example of technical reductionism is Drake and Drabkin's translation of Disputationes de quibusdam placitis Arist[otelis] which excludes some of the most compelling philosophical sections on the definition of space, infinity, and time, thus missing the connection of Benedetti's considerations on fundamental concepts and his treatment of motion through media and void. Cf. Drake and Drabkin (1969, 196-223).
} 
Becchi, Antonio, Domenico Bertoloni Meli, and Enrico Gamba (ed.). 2013. Guidobaldo del Monte (1545-1607): theory and practice of the mathematical disciplines from Urbino to Europe. Berlin: Edition Open Access, http://edition-openaccess.de/proceedings/4/index.html.

Benedetti, Giovanni Battista. 1553. Resolutio omnium Euclidis problematum. Venice: apud Bartholomaeum Caesanum.

Benedetti, Giovanni Battista. 1585. Diversarum speculationum mathematicarum et physicarum liber, Taurini: Apud haeredem Nicolai Bevilaquae.

Biagioli, Mario. 1989. The Social Status of Italian Mathematicians (1450-1600). History of Science 27: 41-95.

Biagioli, Mario. 1993. Galileo, courtier: the practice of science in the culture of absolutism. Chicago-London: The University of Chicago Press.

Biagioli, Mario. 1995. Le prince et les savants: La civilté scientifique au $17^{e}$ siécle. Annales: Historie, Sciences Sociales 6: 1417-1453.

Biagioli, Mario. 1996. Etiquette, interdependence, and sociability in seventeenth-century science. Critical Inquiry 22/2.

Bordiga, Giovanni. [1926] 1985. Giovanni Battista Benedetti, filosofo e matematico veneziano nel secolo XVI, 585-754. Venice: Istituto Veneto di Scienze, Lettere ed Arti.

Brahe, Tycho. 1916. Opera omnia, ed. John Louis Emil Dreyer. Copenhagen: Libraria Gyldendaliana.

Bucci, Agostino. 1583. Disputatio de principatu partium corporis. Torino: Apud haeredes Nicolai Beuilaquae.

Bukharin, Nikolai. 1931. Theory and practice from the standpoint of dialectical materialism. In Science at the cross roads: papers presented to the International Congress of the History of Science and Technology (London, 1931), 9-33. London: Kniga.

Cardano, Girolamo. 1966. Encomium geometriae recitatum anno 1535 in Academia Platina Mediolana. In Opera omnia, vol. 4, 440-445. Lugduni: Sumptibus Ioannis Antonii Huguetan \& Marci Antonii Ravaud, anastatic reprint, Stuttgart-Bad Cannstatt: Fromann-Holzboog.

Catarinella, Annamaria and Irene Salsotto. 1998. L'università e i collegi. In Storia di Torino: Dalla dominazione francese alla ricomposizione dello Stato (1536-1630), vol. 3, ed. Giuseppe Ricuperati, 523-567. Torino: Einaudi.

Cecchini, Michela, and Clara Silvia Roero. 2004. I corrispondenti di Giovanni Battista Benedetti. Physis 41/1: 31-66.

Chalmers, Alan. 2017. One hundred years of pressure: Hydrostatics from Stevin to Newton. Cham: Springer Nature. 
Clark, William. 2006. Academic charisma and the origins of the research university. Chicago: The University of Chicago Press.

Clavius, Christophorus. 1589. Euclidis Elementorum Lib. XV. Rome: Bartholomaeum Grassium.

Cook, Harold John. 2007. Matters of exchange: commerce, medicine, and science in the Dutch Golden Age. New Haven: Yale University Press.

Damerow, Peter, Gideon Freudenthal, Peter McLaughlin and Jürgen Renn. 2004. Exploring the limits of preclassical mechanics: A study of conceptual development in early modern science: Free fall and compounded motion in the work of Descartes, Galileo and Beeckman. Second edition. New York: Springer.

Daston, Lorraine and Peter Galison. 2007. Objectivity. New York: Zone Books,.

De Pace, Anna. 1993. Le matematiche e il mondo: Ricerche su un dibattito in Italia nella seconda metà del Cinquecento. Milano: Franco Angeli.

Di Bono, Mario. 1987. L'astronomia copernicana nell'opera di Giovan Battista Benedetti. In Istituto Veneto di Scienze, Lettere ed Arti: Cultura, scienze e tecniche nella Venezia del Cinquecento, 283-300: Venice: Istituto Veneto di Scienze, Lettere ed Arti.

Dijksterhuis, Eduard Jan. 1956. Archimedes. Copenhagen: Munksgaard.

Doglio, Maria Luisa. 1998. Intellettuali e cultura letteraria (1562-1630). In Storia di Torino: Dalla dominazione francese alla ricomposizione dello Stato (1536-1630), ed. Giuseppe Ricuperati, vol. 3, 599-653. Torino: Einaudi.

Doglio, Maria Luisa. 2005. Dall'Institutio al monumento, introduzione a Carlo Emanuele I di Savoia, Simulacro del vero principe. Alessandria: Edizioni dell’Orso.

Drabkin, I.E. 1960. Introduction to On Motion. In Galileo Galilei, On Motion and On Mechanics. Madison: The University of Wisconsin Press.

Drake, Stillman and I.E. Drabkin. 1969. Mechanics in sixteenth-century Italy. MadisonLondon: The University of Wisconsin Press.

Firpo, Luigi. 1983. Relazioni di ambasciatori veneti al Senato: tratte dalle migliori edizioni disponibili e ordinate, vol. XI. Turin: Bottega di Erasmo.

Galluzzi, Paolo. 1979. Momento: Studi galileiani. Roma: Ed. Dell'Ateneo \& Bizzari.

Gaurico, Luca. 1552. Tractatus astrologicus in quo agitur de praeteritis multorum hominum accidentibus per proprias eorum genituras ad unguem examinatis. Venetiis: Navo.

Giusti, Enrico. 1993. Euclides reformatus. La teoria delle proporzioni nella scuola galileiana. Torino: Bollati Boringhieri.

Goddu, André. 2010. Copernicus and the Aristotelian Tradition: Education, Reading, and Philosophy in Copernicus's Path to Heliocentrism. Leiden: Brill.

Gramsci, Antonio. 1975. Quaderni del carcere, ed. Valentino Gerratana. Turin: Einaudi. 
Granada, Miguel Ángel and Dario Tessicini. 2005. Copernicus and Fracastoro: The dedicatory letters to Pope Paul III, the history of astronomy, and the quest for patronage. Studies in History and Philosophy of Science 36/3: 431-476.

Greenblatt, Stephen. 1980. Renaissance self-fashioning: from More to Shakespeare. Chicago: The University of Chicago Press.

Grendler, Paul F. 2002. I tentativi dei gesuiti d'entrare nelle università italiane tra '500 e '600. In Gesuiti e università in Europa (secoli XVI-XVIII), ed. Gian Paolo Brizzi and Roberto Greci, 37-51. Bologna: CLUEB.

Gui, Francesco. 1989. I Gesuiti e la rivoluzione boema: alle origini della guerra dei trent'anni. Milan: Franco Angeli.

Hellyer, Marcus. 2005. Catholic physics: Jesuit natural philosophy in early modern Germany. Notre Dame, Ind.: University of Notre Dame Press.

Hessen, Boris. 2009. The Social and Economic Roots of Newton's Principia" [1931]. In The Social and Economic Roots of the Scientific Revolution. Texts by Boris Hessen and Henryk Grossmann, ed. Gideon Freudenthal and Peter McLaughlin. Dordrecht: Springer.

Koyré, Alexander. [1939] 1966. Études galiléennes. Paris: Hermann.

Koyré, Alexander. 1966. Jean Baptiste Benedetti, critique d'Aristote. In Études d'histoire de la pensée scientifique, 122-146. Paris: Presses universitaires de France.

Kuhn, Thomas S. 1959. The Copernican revolution: planetary astronomy in the development of western thought. New York: Random House.

Kuhn, Thomas S. 1996. Postscript-1969. In The structures of scientific revolutions. Third Edition. Chicago-London: The University of Chicago Press.

Lagrange, Joseph-Louis (Giuseppe Ludovico). 1788. Mécanique analitique. A Paris: Chez la veuve Desaint.

van Leeuwen, Joyce. 2016. The Aristotelian mechanics: text and diagrams. Cham: Springer.

Lehner, Christoph and Helge Wendt. 2017 Mechanics in the Querelle des Anciens et des Modernes. Isis 108 (1): 26-39.

Lomazzo, Giovan Paolo. 2006. Rime ad imitazione de i grotteschi usati da' pittori. Rome: Vacchiarelli.

Long, Pamela O. 2011. Artisan/practitioners and the rise of the new sciences, 1400-1600. Corvallis: Oregon State University Press.

Maccagni, Carlo. 1967. Le speculazioni giovanili 'de motu’ di Giovanni Battista Benedetti. Pisa: Domus Galilaeana.

Mach, Ernst. 1912. Die Mechanik in ihrer Entwicklung historisch-kritisch Dargestellt. Leipzig: Brockhaus. 
Maier, Anneliese. 1951. Die Impetustheorie. In Zwei Grundprobleme der scholastischen Naturphilosophie, 113-314. Rome: Edizioni di Storia e Letteratura.

Mamino, Sergio. 1989. Scienziati ed architetti alla corte di Emanuele Filiberto di Savoia: Giovan Battista Benedetti. Studi Piemontesi 18: 429-449.

Mammola, Simone. 2013. Una disputa storico-filosofica nella Torino del '500: Agostino Bucci interprete di Parmenide. Rivista di Storia dell'Università di Torino 2/2.

Mammola, Simone. 2014. Il problema della grandezza della terra e dell'acqua negli scritti di Alessandro Piccolomini, Antonio Berga e G.B. Benedetti e la progressiva dissoluzione della cosmologia delle sfere elementari nel secondo '500. Preprint 459. Berlin: Max Plank Institute for the History of Science.

Mulsow, Martin. 2007. Netzwerke gegen Netzwerke: Polemik und Wissensproduktion im politischen Antiquarianismus um 1600. In Die unanständige Gelehrtenrepublik: Wissen, Libertinage und Kommunikation in der Frühen Neuzeit, 143-190. StuttgartWeimar: J. B. Metzler.

Nenci, Elio. 2011. Bernardino Baldi's “In mechanica Aristotelis problemata exercitationes." Berlin: Edition Open Access, http://www.edition-opensources.org/sources/3/index.html.

Norbert, Elias. 2002. Die höfische Gesellschaft. Frankfurt a.M.: Suhrkamp.

Omodeo, Pietro D. 2008. La Stravagantographia di un 'filosofo stravagante. Bruniana \& Campanelliana 14(1), 11-23.

Omodeo, Pietro D. 2009. La cosmologia infinitistica di Giovanni Battista Benedetti. Bruniana \& Campanelliana 15(1): 181-190.

Omodeo, Pietro D. 2012. Renaissance science and literature: Benedetti, Ovid and the transformations of Phaeton's myth after Copernicus. Science \& Education 21: 1-8 (Special Issue on "Science and Literature).

Omodeo, Pietro D. 2014a. Copernicus in the cultural debates of the Renaissance: reception, legacy, transformation. Leiden: Brill.

Omodeo, Pietro D. 2014b. Efemeridi e critica all'astrologia tra filosofia naturale ed etica: La contesa tra Benedetti e Altavilla nel tardo Rinascimento torinese. Preprint 458. Berlin: The Max Planck Institute for the History of Science.

Omodeo, Pietro D. 2014c . Torino, 1593: Motivi dell'opposizione universitaria ai gesuiti nel contesto degli antagonismi europei del tempo. Rivista di Storia dell'Università di Torino 3/(1): 1-18.

Omodeo, Pietro D. 2017a. L'eredità di Boris Hessen: Per un approccio socio-politico alla scienza in età moderna. Afterword in Boris Hessen, Le radici sociali ed economiche della meccanica di Newton, ed. Gerardo Ienna. Roma: Castelvecchi. 
Omodeo, Pietro D. 2017b. Utilitas astronomiae in the Renaissance: The rhetoric and epistemology of astronomy. In The Structures of practical knowledge, ed. Matteo Valleriani. Cham: Springer Nature.

Omodeo, Pietro D. and Jürgen Renn. In press. Science in Court Society: Giovan Battista Benedetti's Diversarum speculationum mathematicarum et physicarum liber. Berlin: Edition Open Access.

Patrizi, Francesco. 1975. Lettere ed opuscoli inediti, ed. Danilo Aguzzi Barbagli. Firenze: Istituto Nazionale di Studi sul Rinascimento.

Pivano, Silvio. 1928. Emanuele Filiberto e le Università di Mondovì e di Torino. In Studi pubblicati dalla Regia Università di Torino nel IV centenario della nascita di Emanuele Filiberto, 1-34. Torino: Università di Torino, Turin.

Pollak, Martha D. 1991. Turin 1564-1680: Urban Design, Military Culture, and the Creation of the Absolutist Capital. Chicago: The University of Chicago Press.

Polyani, Karl. [1944] 2001. The Great Transformation: The Political and Economic Origins of Our Time. Boston: Beacon Press.

Pulte, Helmut. 1989. Des Prinzip des kleinsten Wirkung und die Kraftkonzeptionen der rationalen Mechanik: eine Untersuchung zur Grundlegungsproblematik bei Leonhard Euler, Pierre Louis Moreau de Moupertuis und Joseph Louis Lagrange. Stuttgart: Steiner.

Renn, Jürgen and Peter Damerow. 2010. Guidobaldo del Monte's Mechanicorum Liber. Berlin: Edition Open Access, http://www.edition-open-sources.org/sources/1/index.html.

Renn, Jürgen and Peter Damerow. 2011. The equilibrium controversy: Guidobaldo del Monte's critical notes on the mechanics of Jordanus and Benedetti and their historical and conceptual background. Berlin: Edition Open Access, http://www.edition-opensources.org/sources/2/index.html.

Ricuperati, Giuseppe, ed. 1998. Storia di Torino: Dalla dominazione francese alla ricomposizione dello Stato (1536-1630), vol. 3. Torino: Einaudi.

Roero, Clara Silvia. 1997. Giovan Battista Benedetti and the scientific environment of Turin in the $16^{\text {th }}$ century. Centaurus 39(1): 37-66.

Steinmetz, Dirk. 2010. Die Gregorianische Kalenderreform von 1582: Korrektur der christlichen Zeitrechnung in der Frühen Neuzeit. Oftersheim: Verlag Dirk Steinmetz.

Tessari, Antonio Secondo. 1993. Sul soggiorno di Andrea Palladio a Torino per le questioni militari di Emanuele Filiberto. Studi Piemontesi 22(1): 9-20.

Tonso, Giovanni. 1596. De vita Emmanuelis Philiberti Allobrogum ducis, et Subalpinorum principis, libri duo. Torino: Apud Io. Dominicum Tarinum.

Trotto, Bernardo. 1625. Dialoghi del Matrimonio e vita vedovile... di nuovo ristampati. Torino: Appresso il Pizzaiglio, Stampator Ducale. 
Valleriani, Matteo. 2013. Metallurgy, ballistics, and epistemic instruments: the Nova scientia of Nicolò Tartaglia. Berlin: Edition Open Access, http://www.edition-opensources.org/sources/6/index.html.

Zilsel, Edgar. [1942] 2000. The Sociological Roots of Science. Social Studies of Science 30(6): 935-939.

Ziggelaar, August. 1983. The Papal Bull of 1582: Promulgating a Reform of the Calendar. In Gregorian Reform of the Calendar: Proceedings of the Vatican Conference to Commemorate its 400th Anniversary, ed. George V. Coyne, Michael A. Hoskin and Olaf Pedersen, 201-239. Rome: Pontifical Academy of the Sciences. 